Wildenthal, Lora. Review of Sweeping the German Nation: Domesticity and National Identity in Germany, 1870-1945, by Nancy R. Reagin. The American Historical Review 113, no. 1 (2008): 271-272. doi: 10.1086/ahr.113.1.271.

\title{
Nancy R. Reagin. Sweeping the German Nation: Domesticity and National Identity in Germany, 1870-1945. New York: Cambridge University Press. 2007. Pp. xii, 247. \$75.00
}

\author{
Lora Wildenthal, Rice University
}

This book is a series of intriguing essays organized around the relationship between nationalism and housekeeping in Germany. Nancy R. Reagin draws our attention to a cultural layer of nationalist thinking by and for women, among an "imagined community of German housewives" (p. 69). She draws on prescriptive literature by housekeeping experts, housewives' associations, and government agencies, mostly penned by self-conscious nationalists of the urban middle classes. Reagin shows how these speakers considered housekeeping to be an integral part of German national identity and their own nationalist aspirations. She argues that a bourgeois quest to "invent Germans" after unification in 1870 drove this process (p. 3).

In the chapters that follow, Reagin demonstrates the political relevance of housekeeping in specific eras. Nationalists' politicization of housework was especially vivid during World War I, the Weimar period, under the autarkic Four-Year Plan of the Nazis (1936-1939), and during World War II in occupied Poland. In each of these eras, "understandings of German domesticity and housekeeping were ... increasingly incorporated into public policy" (p. 5). The narrative pivots on the historical moment of World War I, when the German state began to manipulate women by way of a linkage between housekeeping and nationalism that had been established in the preceding years. From that time until 1945, nationalists and state agencies sought to induce women to sacrifice for war and for protectionist policies by urging them to fit their purchases to the state-led market and to use labor-intensive methods (p. 102). Reagin argues for strong continuities between the Weimar and Nazi eras: "Nazi organizations cherry picked, for their own purposes, the notions of housewifery and domesticity that had been popular among conservative housewives' groups before 1933" (p. 111). One example is a 1939 decree requiring a mandatory year of housekeeping service for unmarried women under the age of twenty-five; another is the Hashude Educational Settlement in Bremen (1934-1940), where families judged to be "asocial" were interned. That judgment rested in part on housekeeping. In general, the Nazis "used the symbols and practices of domesticity to support Nazi notions of racial hierarchy and to reshape women's housekeeping to meet the needs of the Nazi Four-Year Plan” (p. 143). The shocking reach of these ideas under the Nazis, underpinned by state power, sometimes leads Reagin to overstate the private or benign nature of nationalist claims about housekeeping before 1933 (e.g., 
pp. 157, 180, and especially 217). If an idea or practice was nationalist —or colonialist, as one passage explores - it was not merely a private matter.

This book is not intended to be a history of how actual German women thought about or carried out domestic tasks. Rather, it is an analysis of prescriptive literature. Reagin makes this distinction clear, but on occasion she grants too much to the authors of her sources. In the [End Page 271] early chapters, Reagin's survey of domesticity norms in the Kaiserreich could have been deepened through a consideration of housekeeping schools and Ann Taylor Allen's work on Hedwig Heyl. Another possibility might have been to trace ideas of housekeeping among propagandists aiming at Auslandsdeutsche throughout the book's chronology, rather than a brief discussion of Kolonialdeutsche and then a longer discussion of the treatment of ethnic Germans in Nazi-era Eastern Europe (Volksdeutsche). There were other Auslandsdeutsche and yet more nationalist ink spilled about their housekeeping (p. 141), although that would have complicated the Kaiserreich-based nationalist agenda that structures Reagin's narrative.

Reagin shows that women settlement advisors in occupied Poland used housekeeping as a criterion for categorizing those whose ethnicity seemed otherwise ambiguous. In that final chapter I did not see as strong a distinction as Reagin indicates between her own focus on "hands-on details of ... resocialization" (p. 200, n. 33) and Elizabeth Harvey's Women and the Nazi East: Agents and Witnesses of Germanization (2003). While I was struck by the similarities between recycling and buy-local campaigns then and now, Reagin claims that the housekeeping styles in the years of this book are "(to people on the left) unattractive" (p. 223). Reagin might have discussed for her readers the intriguing image on the book's cover, a representation of "the" German Hausfrau of the nineteenth century by an artist with a Czech or perhaps Russian name, done in 2006. As the existence of this painting suggests, hers is a vast and rich topic, and an excellent theme through which to discuss cultural aspects of nationalism. 